\title{
USING OF CIRCUMSTANCES IN JOE BIDEN'S INAUGURATION SPEECH FROM ENGLISH TO INDONESIAN TRANSLATION
}

\author{
Muh. Kholiq \\ Gunadarma University, Faculty of Letters and Cultures, Jakarta. Indonesia \\ kholiq040973@gmail.com
}

\begin{abstract}
This research aimed to identify the types of circumstances used in Joe Biden's inauguration speech. This research used the transcript in English version and Indonesian version of Joe Biden's inauguration speech on January 21, 2021 in Washington DC as the source of the data. Furthermore, the researcher applied a qualitative descriptive method of this research. This result of research showed that there are 37 data found in the type of circumstances such as (2) extent, (2) location, manner divided into (3) means, (7) quality, (3) comparison, (3) degree, cause divided into (4) reason, (4) purpose, and (2) behalf. Moreover, accompaniment consists of (1) comitative. Role has (4) guise category, (1) matter, and angle has (1) in viewpoint category. Moreover, the dominant circumstances that present are quality categories in circumstances of manner.
\end{abstract}

Keywords: Joe Biden's inauguration speech; Transitivity; Types of circumstances.

\begin{abstract}
ABSTRAK
Penelitian ini bertujuan untuk mengidentifikasi jenis keadaan yang digunakan dalam pidato pengukuhan Joe Biden. Penelitian ini menggunakan transkrip pidato pengukuhan Joe Biden versi bahasa Inggris dan bahasa Indonesia pada tanggal 21 Januari 2021 di Washington DC sebagai sumber datanya. Selanjutnya peneliti menerapkan metode deskriptif kualitatif dalam penelitian ini. Hasil penelitian ini menunjukkan bahwa terdapat 37 data yang ditemukan pada tipe keadaan seperti (2) luas, (2) lokasi, cara dibagi menjadi (3) sarana, (7) kualitas, (3) perbandingan, (3) derajat, sebab dibagi menjadi (4) alasan, (4) tujuan, dan (2) nama. Sedangkan pengiring terdiri dari (1) komitatif. Peran memiliki (4) kategori kedok, (1) materi, dan sudut memiliki (1) dalam kategori sudut pandang. Selain itu, keadaan dominan yang hadir adalah kategori kualitas dalam keadaan sikap.
\end{abstract}

Kata Kunci: Pidato Pengukuhan Joe Biden; Transitivitas; Jenis Keadaan.

\section{INTRODUCTION}

This research concerned the transitivity theory based on the Systemic Functional Linguistics approach proposed by Halliday. Transitivity is a branch study of ideational metafunction in systemic functional grammar (SFL) that a function of language used to become reasonable in experience and social neighborhood by 
humans. Ideational metafunction is divided into the experiential and the logic. Whereas, the transitivity holds the experiential category, it uses to describe the meaning of content and the experience at the clause level of language used by construing the relationship between the human itself and other humans in social neighborhood (Halliday \& Matthiessen, 2014).

Learning in the circumstance of practice has been the most widespread and long-lasting way of learning vocations throughout human history. Learning through practice has been the most common and central means of building the professional capabilities that are important to the existence and advancement of societies and communities throughout history and, presumably, consistently throughout continents, regions, and cultures. Occupational capacities have been learned in the most prevalent and long-lasting ways throughout human history, and are most likely still being learned today. However, there is no comprehensive account of this kind of learning, limiting the legitimacy of workplaces as learning venues, the learning that occurs there, and understandings of how to organize, promote, and evaluate that learning. (Billet, 2014).

This means a clause as the significance of unit process to determine the different kinds of meaning in grammatical rules. Therefore, transitivity is a system that belongs to grammatical rules specifically of the clause to interpret the language used through the process of making the meaning of the world and meaning of experience by humans in communication activities.

In this study, the author is interested in conducting the research of types of circumstances used in Joe Biden's inauguration speech on January 21, 2021 and which are more frequently used in the types of circumstances in Joe Biden's inauguration speech on January21, 2021.

\section{LITERATURE REVIEW}

In transitivity, a clause is a representation that manifests in a three kinds of transitivity structure such as process, participants and circumstances. (Gerot \& Wignell, 1994) define that the process is concerned with the relationship between a verb and the action it is doing in clauses and sentences. Hence, the process is the first important thing in transitivity which refers to an activity that occurs and word class of the verb. Meanwhile, participants in transitivity can refer to an object or person in which an activity or process occurs. Circumstance refers to the situation and the neighborhood of the participant while the process happened. Moreover, (Saragih, 2010) considers that circumstance relates to adverbs and occurs when the process represents the situation and around of the participants, it is the circumstances. The notion of circumstance, (Halliday \& Matthiessen, 2014) defines as a means that describe the situation in a process, the location that refers to the time or space in the WH form. Also, circumstance is showing the preposition phrase for the adverbial group and the group of nouns (p. 220). 
Further, they classify the circumstance into nine types within of the difference functions, as follows: extent, location, manner (means, quality, comparison, degree), cause (reason, purpose, behalf), accompaniment (comitative, additive), angle (source, viewpoint), contingency (condition, concession, default), role (guise, product), and matter. Hence, the researcher thinks that analyzing the circumstance is focusses of the process among the participants and the circumstances at the clause extent, especially in the transcript of Joe Biden's speech of his inauguration as the President of America on January 21, 2021.

The researcher finds out the previous research that has utilized circumstances analysis, as follows. The first previous research was written by (Tilusubya, Nababan \& Santosa, 2018) from Sebelas Maret University. This study analyzed the circumstances of translation in the gospel of Matthew chapter 12 through 14 with regard to transitivity. The objectives of this study are to analyze the translation technique of circumstances and to observe the quality of the translation based on accuracy and acceptability. This study used a descriptive qualitative method. The data was collected based on document analysis and focus group discussion. The results of this study showed that there are data found in the form of circumstances or an adverb such as the application of established equivalent, combination, modulation, transposition, paraphrasing, deletion, explicitation, discursive creation, and implicitation techniques.

The second previous study was written by Puji Suhada Ramadani (2018) from University of Muhammadiyah Sumatera Utara. This study analyzed the circumstances in Donald Trump's Speech. The objectives of this study are to elaborate the types of circumstances, how used the circumstances in Donald Trump's Speech and why circumstances used in Donald Trump's Speech. This study analyzes Donald Trump's Speech through the script of 'United Nations General Assembly' on Sept 19, 2017 in 42 minutes duration. This study used qualitative research design. The results of this study reveals that there were circumstances of extent that have the total 0 for spatial and 3 for temporal, circumstances of location have 34 for spatial and 5 for temporal, and circumstances of manner have a 3 for means, 1 for quality and 2 for comparison. Therefore, the most dominant type of circumstances that found in Donald Trump's Speech is location.

\section{RESEARCH METHOD}

The researcher uses qualitative approach as the methodology because this data research analyzes in descriptively. As stated by (Bogdan, 2006) qualitative approach as a method that develops descriptive data in the form of written words or the utterance and manner by humans that can be analyzed by the research. Also, this approach assists the researcher to understand and find the data that is related to this problem research. Strauss and Corbin in (Cresswel, 2010) points out the qualitative research as a procedure that can be analyzed on the human's lives, manner, history, 
activities at society and others (p.24). Whereas, (Kumar, 2010) appends that the aim of qualitative research is to describe the various categories of events, situations or behavior, and it can be identified. Moreover, Ranjit says there is related research of it which is descriptive research. As Ranjit said in his books that descriptive research is a procedure that is used with the aims 'to describe a situation, phenomenon, problem or issue' in research. (p. 15). Hence, qualitative is a research method that assists the researchers to describe and analyze the data based on the phenomenon on the speaker's words, speech or behavior descriptively.

The source data of this research is taken from two online newspapers about President Biden's inauguration speech on January 21, 2021 in Washington DC. The first source is English version from BBC News.com and Indonesian version from Detik news.com. Both news sites are transcript articles of Joe Biden's first speech as the 46th president of the United States after he took the oath of office. Also, he said this democratic victory (Permana, 2021). This source data is chosen to analyze the type of circumstance used by the speaker. According to (Moleong, 2007) data analysis is the process of constructing the data in order into a pattern element and description of the data. Further, before the researcher analyzes the data, it should need a technique of collecting the data which the researcher uses as a documentation technique. (Sugiyono, 2013) points out that the documentation technique utilizes to obtain the information in the writing or image form that can be done through identification, classification, and categorization by collecting the data of data sources into several sentences. This technique is a way to assist researchers to organize their ideas based on data and problems related to theory of the research. Therefore, this research method focuses on discussing the data that is related to translation study in analyzing the circumstances used by Joe Biden's speech.

\section{FINDING AND DISCUSSION}

This part provides the result and discussion which is aimed to answer the problems of formulation based on the theory of types of circumstances by Halliday \& Matthiessen (2014) in Joe Biden's inauguration speech on January 21, 2021. This research discovered that there are (2) extent, (2) location, manner divided into (3) means, (7) quality, (3) comparison, (3) degree, cause divided into (4) reason, (4) purpose, and (2) behalf. Moreover, accompaniment consists of (1) comitative. Role has (4) guise category, (1) matter. The last, angle has (1) viewpoint category.

\section{Extent}

Circumstance of extent is used to describe a process in for distance: how far? for duration: how long? and for frequency: how many times? (Halliday \& Matthiessen (2014). Those are the data found in Joe Biden's inauguration speech.

\begin{tabular}{|l|l|l|}
\hline No & Source Language & Target Language \\
\hline
\end{tabular}




\begin{tabular}{|l|l|l|}
\hline 1 & $\begin{array}{l}\text { A once in a century virus that } \\
\text { silently stalks the country has } \\
\text { taken as many lives in one } \\
\text { year as in all of World War } \\
\text { Two. }\end{array}$ & $\begin{array}{l}\text { Virus yang muncul sekali dalam seabad } \\
\text { diam-diam mengintai negara ini dalam } \\
\text { satu tahun sudah merenggut nyawa } \\
\text { sebanyak seluruh korban Amerika } \\
\text { dalam Perang Dunia II. }\end{array}$ \\
\hline 2 & $\begin{array}{l}\text { A cry for racial justice, some } \\
\mathbf{4 0 0} \text { years in the making, } \\
\text { moves us. }\end{array}$ & $\begin{array}{l}\text { Seruan untuk keadilan rasial yang } \\
\text { berkumandang selama 400 tahun } \\
\text { menggerakkan kita. }\end{array}$ \\
\hline
\end{tabular}

The data above are categorized in the circumstance of extent. From the first data in the source language one year is translated satu tahun in the target language which constructs the duration in the circumstance of extent. It describes the duration of the virus that took many lives in World War Two in one years. Moreover, the second data also describes the duration of circumstance of extent which is $\mathbf{4 0 0}$ years old in the source language. It describes the duration of a racial justice that has moved the people for 400 years.

\section{Location}

Halliday \& Matthiessen (2014) defines the circumstance of location and describes the process of the location, namely the place where the incident takes place both in space and time. This type of circumstance is explained in the form of a question where? marked by an adverbial group or prepositional phrase, such as by the door, down, at the market, long ago, since the foundation of the world, at the end of the age, at the fourth our of the watch, and on the top of the building.Here are the data found in Joe Biden's inauguration speech, such as;

\begin{tabular}{|l|l|l|}
\hline No & Source Language & Target Language \\
\hline 1 & $\begin{array}{l}\text { So, now on this hallowed } \\
\text { ground where just a few } \\
\text { days ago violence sought } \\
\text { to shake the Capitol's very } \\
\text { foundations. }\end{array}$ & $\begin{array}{l}\text { Jadi saat ini, di tempat sacral ini, di mana } \\
\text { beberapa hari yang lalu kekerasan } \\
\text { berusaha untuk mengguncang landasan } \\
\text { Capitol ini }\end{array}$ \\
\hline 2 & $\begin{array}{l}\text { Here we stand, looking } \\
\text { out on the great Mall, } \\
\text { where Dr. King spoke of } \\
\text { his dream. }\end{array}$ & $\begin{array}{l}\text { Di sini kita berdiri menghadap ke alun-alun } \\
\text { besar tempat Dr. King berbicara tentang } \\
\text { mimpinya. }\end{array}$ \\
\hline
\end{tabular}

From the data above, it is clear that these express the circumstance of location. In the first data, a few days ago described the time of the violence sought to shake the Capitol's very foundations and in the second data, on the great Mall described the place of people who stood where Dr. King spoke of his dream.

\section{Manner}

Halliday \& Matthiessen (2014) divided types of circumstance of manner 
into three categories, such as means, quality, comparison and degree.

\subsection{Means}

Circumstance of means is a process that occurs in which this category is explained by the preposition by or with and in the form of the question how? what with? Here is the data that represents the circumstance of means.

\begin{tabular}{|l|l|l|}
\hline No & Source Language & Target Language \\
\hline 1 & $\begin{array}{l}\text { Many centuries ago, St } \\
\text { Augustine - the saint of my } \\
\text { church - wrote that people was } \\
\text { a multitude defined by the } \\
\text { common objects of their love. }\end{array}$ & $\begin{array}{l}\text { Berabad-abad yang lalu, Santo } \\
\text { Agustinus, orang kudus dalam agama } \\
\text { saya, menulis bahwa suatu umat dinilai } \\
\text { dari hal-hal yang sama-sama mereka } \\
\text { cintai. }\end{array}$ \\
\hline 2 & $\begin{array}{l}\text { We will be judged, you and I, } \\
\text { by how we resolve these } \\
\text { cascading crises of our era. }\end{array}$ & $\begin{array}{l}\text { Kita akan dihakimi, anda dan saya, atas } \\
\text { cara kita menyelesaikan krisis yang } \\
\text { hadir di saat ini. }\end{array}$ \\
\hline 3 & $\begin{array}{l}\text { Sustained by faith, driven by } \\
\text { conviction and devoted to one } \\
\text { another and the country we } \\
\text { love with all our hearts. }\end{array}$ & $\begin{array}{l}\text { Ditopang oleh iman. Didorong oleh } \\
\text { keyakinan dan berbakti satu sama lain } \\
\text { dan kita cintai negara ini dengan } \\
\text { segenap hati kita. }\end{array}$ \\
\hline
\end{tabular}

The data above is expressed by the circumstance of means. It can be seen from the first data, Joe Biden said that St Augustine wrote that people can be seen from what the things that they love are. That means, it refers to what people can see, it is from the things that they love. Further, the second data is ...driven by conviction... means Joe Biden said it can be driven with conviction, which is conviction is the process to drive something. Hence it can be concluded as circumstance of means because the data use prepositions by.

\subsection{Quality}

Circumstance of quality is used with characteristics such as followed by adverbs as head of -ly, followed by prepositional phrases in and the noun or nominal group of "manner", either manner or way, or of a qualitative dimension such as speed, tone, skill, ease, difficulty, and term.

\begin{tabular}{|l|l|l|}
\hline No & Source Language & Target Language \\
\hline 1 & $\begin{array}{l}\text { As we look ahead in our } \\
\text { uniquely American way, } \\
\text { restless, bold, optimistic, and } \\
\text { set our sights on a nation }\end{array}$ & $\begin{array}{l}\text { Kita melihat ke depan dengan cara kita } \\
\text { yang khas Amerika resah, berani, } \\
\text { optimis dan bertekad menjadi bangsa } \\
\text { seharusnya. }\end{array}$ \\
\hline 2 & $\begin{array}{l}\text { Over the centuries through } \\
\text { storm and strife in peace and }\end{array}$ & $\begin{array}{l}\text { Selama berabad-abad melalui badai dan } \\
\text { perselisihan, dalam damai dan }\end{array}$ \\
\hline
\end{tabular}




\begin{tabular}{|c|c|c|}
\hline & in war we've come so far. & perang, kita telah sampai sejauh ini. \\
\hline 3 & $\begin{array}{l}\text { We'll press forward with } \\
\text { speed and urgency for we } \\
\text { have much to do in this winter } \\
\text { of peril and significant } \\
\text { possibility. }\end{array}$ & $\begin{array}{l}\text { Kita akan terus maju dengan cepat dan } \\
\text { segera, karena banyak yang harus kita } \\
\text { lakukan di musim dingin yang penuh } \\
\text { bahaya dan kemungkinan ini. }\end{array}$ \\
\hline 4 & $\begin{array}{l}\text { A once in a century virus that } \\
\text { silently stalks the country has } \\
\text { taken as many lives in one year } \\
\text { as in all of World War Two. }\end{array}$ & $\begin{array}{l}\text { Virus yang muncul sekali dalam seabad } \\
\text { diam-diam mengintai negara ini dalam } \\
\text { satu tahun sudah merenggut nyawa } \\
\text { sebanyak seluruh korban Amerika } \\
\text { dalam Perang Dunia II. }\end{array}$ \\
\hline 5 & $\begin{array}{l}\text { We can treat each other with } \\
\text { dignity and respect. we can } \\
\text { join forces, stop the shouting } \\
\text { and lower the temperature. }\end{array}$ & $\begin{array}{l}\text { Kita bisa memperlakukan satu sama } \\
\text { lain dengan bermartabat dan rasa } \\
\text { hormat. Kita bisa menyatukan } \\
\text { kekuatan, menghentikan teriakan, dan } \\
\text { menurunkan ketegangan. }\end{array}$ \\
\hline 6 & $\begin{array}{l}\text { Look, I understand that many } \\
\text { of my fellow Americans view } \\
\text { the future with fear and } \\
\text { trepidation. }\end{array}$ & $\begin{array}{l}\text { Saya memahami bahwa banyak orang } \\
\text { Amerika memandang masa depan } \\
\text { dengan rasa takut dan keraguan. }\end{array}$ \\
\hline 7 & $\begin{array}{l}\text { We will repair our alliances, } \\
\text { and engage with the world } \\
\text { once again. }\end{array}$ & $\begin{array}{l}\text { Kita akan memperbaiki aliansi kita dan } \\
\text { bekerjasama dengan dunia sekali lagi. }\end{array}$ \\
\hline
\end{tabular}

The researcher concluded that the data above are circumstance of quality because there is an adverb -ly in the source language uniquely and silently. Also, the translation above used prepositions in which followed by nouns in peace and in war in the source language. Further, it uses preposition with which followed by a nominal group of speed like with speed and urgency in the source language.

\subsection{Comparison}

This category of circumstance is used as a comparison of likes or unlike of prepositional phrases, or as adverbs to similarity or dissimilarity from an event. Here are the data that represent the circumstance of comparison.

\begin{tabular}{|l|l|l|}
\hline No & Source Language & Target Language \\
\hline 1 & $\begin{array}{l}\text { I know speaking of unity can } \\
\text { sound to some like a foolish } \\
\text { fantasy these days. }\end{array}$ & $\begin{array}{l}\text { Saya tahu berbicara tentang persatuan } \\
\text { bagi beberapa orang terdengar seperti } \\
\text { khayalan yang bodoh. }\end{array}$ \\
\hline 2 & Distrusting those who don't & Tidak mempercayai mereka yang tidak \\
\hline
\end{tabular}




\begin{tabular}{|l|l|l|}
\hline & $\begin{array}{l}\text { look like you or worship the } \\
\text { way you do. }\end{array}$ & $\begin{array}{l}\text { terlihat seperti Anda, atau tidak punya } \\
\text { keyakinan seperti Anda }\end{array}$ \\
\hline 3 & $\begin{array}{l}\text { A story that might sound like } \\
\text { a song that means a lot to me, } \\
\text { it's called American Anthem. }\end{array}$ & $\begin{array}{l}\text { Ini adalah cerita yang mungkin terdengar } \\
\text { seperti lagu yang sangat berarti bagi } \\
\text { saya. }\end{array}$ \\
\hline
\end{tabular}

In the source language above used comparison of like, which explain similarity and it is translated seperti in the target language. From the first data, the comparison is like a description of Joe Biden's utterance that he thought that speaks of unity for some people similarity with a foolish fantasy these days. Also, it is the same with the second data that from Joe Biden's utterance, his thoughts that he's speech sounds like a song which means a lot for him.

\subsection{Degree}

The other subtype of circumstance in manner is degree which is used to describe adverbial groups in general, namely much, a good deal, a lot, or deeply, profoundly, completely, heavily. The researcher found data that belongs to circumstance of degree, as follows;

\begin{tabular}{|l|l|l|}
\hline No & Source Language & Target Language \\
\hline 1 & $\begin{array}{l}\text { Much to do, much to heal, } \\
\text { much to restore, much to } \\
\text { build and much to gain. }\end{array}$ & $\begin{array}{l}\text { Banyak yang harus diperbaiki. Banyak } \\
\text { yang harus dipulihkan. Banyak yang bisa } \\
\text { disembuhkan. Banyak yang harus } \\
\text { dibangun. Dan banyak yang harus diraih. }\end{array}$ \\
\hline 2 & $\begin{array}{l}\text { To overcome these } \\
\text { challenges, to restore the soul } \\
\text { and secure the future of } \\
\text { America, requires so much } \\
\text { more than words. }\end{array}$ & $\begin{array}{l}\text { Untuk mengatasi tantangan ini - untuk } \\
\text { memulihkan jiwa dan mengamankan } \\
\text { masa depan Amerika - dibutuhkan lebih } \\
\text { dari kata-kata. }\end{array}$ \\
\hline 3 & $\begin{array}{l}\text { It's time for boldness for } \\
\text { there is so much to do. }\end{array}$ & $\begin{array}{l}\text { Ini adalah saatnya untuk keberanian, } \\
\text { karena banyak yang harus dilakukan. }\end{array}$ \\
\hline
\end{tabular}

The above of all source languages used prepositions much to explain as adverbs and the level of something occurs. In the first data, prepositions much in translated banyak in the target language. The preposition much in the source language explains the verb of do, heal, restore, build and gain which means much as an adverb. Also, in the target text as the adverb which explained the verb and the level of something that Joe Biden's uttered. Further, the second data of preposition much is translated lebih in the target language. The preposition much depicted of requires which is verb and explains the degree of the Joe Biden's utterance is much more than words which is translated lebih dari kata-kata. 


\section{Cause}

Cause is a part of a type of circumstance which is used to explain the reasons for the condition of a process that occurs, the purpose or purpose of a process related to an incident, and behalf of explaining a cause which refers to the participant. Therefore, Halliday \& Matthiessen (2014) divide circumstance of cause into three categories, namely reason, purpose and behalf which are explained as follows;

\subsection{Reason}

Circumstance of reason is used to find out the reasons why this can happen and what causes it. This type has the meaning "because" which is investigated in the interrogative form why? or how? Further, this type is characterized by using prepositional phrases through, from, for, because of, a result of, thanks to, and due to. Here is the data found by researchers that represent the circumstance of reason.

\begin{tabular}{|l|l|l|}
\hline No & Source Language & Target Language \\
\hline 1 & $\begin{array}{l}\text { It's time for boldness for there } \\
\text { is so much to do. }\end{array}$ & $\begin{array}{l}\text { Ini adalah saatnya untuk keberanian, } \\
\text { karena banyak yang harus } \\
\text { dilakukan. }\end{array}$ \\
\hline 2 & $\begin{array}{l}\text { We can join forces, stop the } \\
\text { shouting and lower the } \\
\text { temperature, forwithout unity } \\
\text { there is no peace. }\end{array}$ & $\begin{array}{l}\text { Kita bisa menyatukan kekuatan, } \\
\text { menghentikan teriakan, dan } \\
\text { menurunkan ketegangan, karena } \\
\text { tanpa persatuan, tidak ada } \\
\text { kedamaian. }\end{array}$ \\
\hline 3 & $\begin{array}{l}\text { When he put pen to paper the } \\
\text { president said, and I quote, 'if } \\
\text { my name ever goes down in } \\
\text { history, it'll be for this act, and } \\
\text { my whole soul is in it'. }\end{array}$ & $\begin{array}{l}\text { Ketika dia meletakkan pena di atas } \\
\text { kertas, Presiden berkata, "Jika nama } \\
\text { saya tercatat dalam sejarah, karena } \\
\text { tindakan inilah dan seluruh jiwa } \\
\text { saya ada di dalamnya." }\end{array}$ \\
\hline 4 & $\begin{array}{l}\text { We'll press forward with speed } \\
\text { and urgency for we have much } \\
\text { to do in this winter of peril } \\
\text { and significant possibility. }\end{array}$ & $\begin{array}{l}\text { Kita akan terus maju dengan cepat dan } \\
\text { segera, karena banyak yang harus } \\
\text { kita lakukan di musim dingin yang } \\
\text { penuh bahaya dan kemungkinan } \\
\text { ini. }\end{array}$ \\
\hline
\end{tabular}

From the bolded data above is the circumstance of reason. In the source language of those data use prepositions for which are translated karena in the target language. As we can see from the first data, it describes now as the right time to show the boldness, and the reason for it in the source language for there is so much to do is translated karena banyak yang harus dilakukan. That is clearly the reason why it happened. Also, the second data explains that 
the Americans can do all of the things related to the national as long as they are together such as we can join forces, stop the shouting and lower the temperature. The reason for it is clearly in for without unity there is no peace which is translated karena tanpa persatuan, tidak ada kedamaian. The researcher determined that the data above is reason, as stated by Halliday \& Matthiessen (2014) reason has meaning of "because" and use of preposition for which can be seen in the data above.

\subsection{Purpose}

Circumstance of purpose is used to determine the purpose of an action or event in a phenomenon that occurs. These subcategories are characterized by prepositional phrases for, in the hope of, for the purpose of, and for the sake of and are investigated on the question what for?

\begin{tabular}{|l|l|l|}
\hline No & Source Language & Target Language \\
\hline 1 & $\begin{array}{l}\text { President Carter, who I spoke } \\
\text { with last night who cannot be } \\
\text { with us today, but who we salute } \\
\text { for his lifetime of service. }\end{array}$ & $\begin{array}{l}\text { Presiden Carter, yang saya ajak bicara } \\
\text { adi malam, tetapi tidak dapat hadir } \\
\text { bersama kita hari ini. Namun, kita } \\
\text { berikan penghormatan atas jasanya } \\
\text { seumur hidup. }\end{array}$ \\
\hline 2 & $\begin{array}{l}\text { Thousands of protesters tried to } \\
\text { block brave women marching } \\
\text { for the right to vote. }\end{array}$ & $\begin{array}{l}\text { Ribuan pengunjuk rasa mencoba } \\
\text { menghalangi para perempuan } \\
\text { pemberani yang berbaris untuk } \\
\text { mendapatkan hak memilih. }\end{array}$ \\
\hline 3 & $\begin{array}{l}\text { If we are that way our country } \\
\text { will be stronger, more } \\
\text { prosperous, more ready for the } \\
\text { future. }\end{array}$ & $\begin{array}{l}\text { Jika kita seperti itu, negara kita akan } \\
\text { menjadi lebih kuat, lebih sejahtera, } \\
\text { lebih siap untuk masa depan. }\end{array}$ \\
\hline 4 & $\begin{array}{l}\text { There is truth and there are lies. } \\
\text { Lies told for power and for } \\
\text { profit. }\end{array}$ & $\begin{array}{l}\text { Ada kebenaran dan ada kebohongan. } \\
\text { Kebohongan disampaikan demi } \\
\text { kekuasaan dan keuntungan. }\end{array}$ \\
\hline
\end{tabular}

The data above used preposition for in the source language which is translated untuk in the target language. Moreover, it follows the purpose of those actions that can be seen in the first data. Joe Biden commands all of the people who attend there, give a salute for President Carter, who cannot attend, but at least it is worth it because of his lifetime of service in America. Besides, the second data also explained the purpose after using preposition for. That means, the purpose by the thousands of protesters is to get the right to vote. It can be concluded, all of the action has the purposes behind it.

\subsection{Behalf}


Halliday \& Matthiessen (2014) defines that behalf describes the entity to the participants on whose name or interest or for whom the action is carried out. Circumstance of behalf is marked by the prepositional phrase for, for the sake of, in favor of, on behalf of. However, it also expresses in the form of interrogative who for?

\begin{tabular}{|l|l|l|}
\hline No & Source Language & Target Language \\
\hline 1 & $\begin{array}{l}\text { I pledge this to you. I will be a } \\
\text { President for all Americans. }\end{array}$ & $\begin{array}{l}\text { Saya akan menjadi Presiden untuk } \\
\text { semua orang Amerika. }\end{array}$ \\
\hline 2 & $\begin{array}{l}\text { There's one verse that stands out } \\
\text { at least for me. }\end{array}$ & $\begin{array}{l}\text { Ada satu syair yang berkesan bagi } \\
\text { saya. }\end{array}$ \\
\hline
\end{tabular}

As we can see from data above, those are circumstances of behalf used as prepositional phrases for in the source language. Further, it is translated untuk in the target language. From the two data it is clear that discussing the action in the data refers to someone. It can be seen in the first data, Joe Biden said that he will be a president for all people in America means he will be a fair president and he's utterance refers to all of the humans in America. Furthermore, in the second data, it refers to Joe Biden himself that he explains there is a verse that he likes.

\section{Accompaniment}

Circumstance of accompaniment explains the process to the participants and explains the meaning which refers to circumstance and, or, not. Also, described in the interrogative form who / what else? Furthermore, Halliday \& Matthiessen (2014) is divided into two categories, namely comitative and additive.

\subsection{Comitative}

As stated by Halliday \& Matthiessen (2014) comitative expresses a process in which a single participant is involved. This subcategory uses prepositional phrases, namely with, without, besides, instead of. Here is the data that was found by the researcher in Joe Biden's inauguration speech.

SL : Before God and all of you, I give you my word. I will always level with you.

TL : Di hadapan Tuhan dan kalian semua, saya berjanji. Saya akan selalu berkata jujur kepada anda.

From the data above, the researcher considered it is comitative because there is a prepositional phrase with in the source language, and it is translated kepada anda in the target language. Moreover, after the prepositional phrase with there followed by the single pronoun you in the source language become anda which is the formal pronoun in the target language.

\section{Role}


Circumstance of role analyzes about the meaning of "be" dan "become". This type is related to the value of the clause an "intensive relational ${ }^{\text {ee }}$. Further it involved Guise and Product categories (Halliday \& Matthiessen, 2014).

\subsection{Guise}

The category in the circumstance of role type is used to find out the meaning of "be" which is related to the identity of participant or objects. Halliday \& Matthiessen (2014) explain that this sub-category is the form of the questionwhat as? and marked with prepositions bywayof,intherole/shape/guise/formof. There are data of guise that found by the researcher, such as;

\begin{tabular}{|l|l|l|}
\hline No & Source Language & Target Language \\
\hline 1 & $\begin{array}{l}\text { We come together as one } \\
\text { nation under God. }\end{array}$ & $\begin{array}{l}\text { Kita berkumpul sebagai satu bangsa, } \\
\text { di bawah naungan Tuhan }\end{array}$ \\
\hline 2 & $\begin{array}{l}\text { We can see each other not as } \\
\text { adversaries butas neighbours. }\end{array}$ & $\begin{array}{l}\text { Kita bisa melihat satus ama lain bukan } \\
\text { sebagai musuh, tapi sebagai } \\
\text { tetangga. }\end{array}$ \\
\hline 3 & $\begin{array}{l}\text { What are the common objects } \\
\text { we as Americans love. }\end{array}$ & $\begin{array}{l}\text { Hal-halapa yang sama-samakitacintai } \\
\text { yang menjadikankita sebagai orang } \\
\text { Amerika? }\end{array}$ \\
\hline 4 & $\begin{array}{l}\text { And each of us has a duty and a } \\
\text { responsibility ascitizens as } \\
\text { Americans and especially as } \\
\text { leaders. }\end{array}$ & $\begin{array}{l}\text { Dan kita masing-masing memiliki } \\
\text { tugas dan tanggungjawab, sebagai } \\
\text { warga negara, sebagai orang } \\
\text { Amerika, dan terutama sebagai } \\
\text { pemimpin }\end{array}$ \\
\hline
\end{tabular}

In the data above, the researcher found four data that represent guise which marks preposition as in the source language, and it is translated sebagai in the target language. Further, the preposition as followed by the participants or identity. As we can see in the first data, the preposition as followed by identity one nation which is translated satu bangsa, it represents that people in America as one nation. Also, in the second data, preposition as followed by identity of adversaries and neighbours which is translated become musuh dan tetangga. It shows that the Americans are together as one nation not as adversaries, while they are a good neighbor.

\section{Matter}

According to Halliday \& Matthiessen (2014), circumstance of matter relates to the situation or causes in a phenomenon with the prepositions about, concerning, with reference to and of. This type of circumstance refers to a verbal or verbiage process, this process itself is a process that describes or refers to objects and services compared to information on a phenomenon that occurs and it 
examines the question what about?. Here is the data found in the Joe Biden inauguration speech that represents of matter;

SL : I understand they worry about their jobs.

TL : Saya mengerti mereka khawatir tentang pekerjaan mereka.

Based on the data above, the words that bolded it matter because in the source language about that has equivalents translated into tentang in the target language. Therefore, the data belongs to the circumstance of matter. Also, the word of about refers to services which are jobs.

\section{Angle}

Circumstance of angle is concerned with verbal processes that discuss in verbal clause "as...says" and in the mental clause "as...thinks", and it contains source and viewpoint categories.

\subsection{Viewpoint}

Halliday \& Matthiessen (2014) categorized viewpoints into circumstances of angle to identify information conveyed in a phoneme that occurs with someone's point of view. This category describes the prepositions to or in the view / opinion of, from the standpoint of. The researcher found the data that represent of viewpoint, as follows;

SL : A story that might sound like a song that means a lot to me.

TL : Cerita yang mungkin terdengar seperti lagu yang sangat berarti bagi saya.

In the data that is bolded in the source language and the target language are equivalent translations of to me which is translated berarti bagi saya. From the data, there is a preposition to and followed by me which is the emphasis of the information or view point of Joe Biden that discusses the story that sounds like a song which means so mean for him/Joe Biden.

The findings of this research are expected to be useful theoretically, the study is expected to add up new horizon in linguistic, especially to the types of circumstances, and practically, the result of research can be useful for those who are interested in studying linguistic and interested in conducting any further studies in process and circumstance.

\section{CONCLUSION}

Based on the result and discussion, the researcher concluded that the types of circumstance of Joe Biden's inauguration speech found are extent has two data, location has two data, manner which consists of means have three data, quality has seven data, comparison in three data, and degree in three data. Further, cause consists of reason has four data, purpose has four data, and behalf has two data. Moreover, 
accompaniment there is comitative and has one data. Role has four data of guise category. Matter has one data. The last, angle has one data view point category. The researcher saw that the circumstances are marked with the prepositional phrases in analyzes of the process of circumstances. Hence, the researcher identified the dominant type of circumstance is the quality category of circumstance of manners. As mentioned in the result and discussion part, the quality category is dominant because Joe Biden's utterance in his inauguration speech used prepositions in and with.

\section{BIBLIOGRAPHY}

Bogdan, R. C. (2006). Qualitative research for education: an introduction to theories and methods (5 ed.). Boston: Sari Knopp Bikle. Google Scholar

Billett, Stephen (2014). Learning in the circumstances of practice. International Journal of Lifelong Education, 33(5), 674693. doi:10.1080/02601370.2014.908425

Catford, J.C. (1967). A Linguistic Theory of Translation. Oxford: Oxford University Press. https://salahlibrary.files.wordpress.com/2017/03/a-linguistic-theory-oftranslation.pdf

Creswell, J. W. (2010). Research design: pendekatan kualitatif, kuantitatif, dan mixed. Yogyakarta: PT Pustaka Pelajar. Google Scholar

Gerot, L. and Wignell, P. 1994. Making Sense of Functional Grammar. Queensland: Gerd Stabler, AEE Publishing. Google Scholar

Halliday, M. A. K. \& Matthiessen, C. M. I. M. (2014). Halliday's introduction to functional grammar (4th Ed.). London: Routledge. https://doi.org/10.4324/9780203431269.

Kumar, Ranjit. 2010. Research Methodology: A Step-by-Step Guide for Beginners, EdisiKetiga. London: Sage Publication. https://corladancash.com/wpcontent/uploads/2020/01/Research-Methodology-Ranjit-Kumar.pdf

Moleong, L. J. (2007). Metode penelitian kualitatif. Bandung: PT. Remaja Rosda Karya. http://rosda.co.id/pendidikan-keguruan/486-metodologi-penelitiankualitatif-edisi-revisi.html

News, B. (2021, January 20). Full transcript of Joe Biden's inauguration speech. Retrieved from BBC News: https://www.bbc.com/news/world-us-canada55656824.

Permana, R. H. (2021, Januari 21). Ini Pidato Lengkap Joe Biden Usai Dilantik Jadi Presiden AS. Retrieved from Detiknews: https://news.detik.com/internasional/d-5342254/ini-pidato-lengkap-joe-bidenusai-dilantik-jadi-presiden-as.

Ramadani, P. S. (2018). Circumstances In Donald Trump's Speech. (Doctoral 
dissertation). Google Scholar

Saragih, A. (2010). Introducing Systemic Functional Grammar of English. Medan: FBS UNIMED. Google Scholar

Sugiyono. (2013). Metode penelitian kuantitatif dan kualitatif. R \&. D. BANDUNG: ALFABETA. Google Scholar

Tilusubya, B., Nababan, M., \& Santosa, R. (2018). Translation analysis of circumstances in the Gospel of Matthew Chapter 12 through 14 from English into Indonesian. Lingua Cultura. https://doi.org/10.21512/lc.v12i4.4608

Thompson, G. (2013). Introducing functional grammar. Routledge. Google Scholar 